\title{
THE COMPARATIVE STUDY OF DOWRY REGULATIONS IN INDONESIA AND MOROCCO LEGISLATIONS
}

\begin{abstract}
Ali Trigiyatno ${ }^{1}$
ABSTRACT

This article compares dowry regulations in Indonesia and Morocco. Bearing in mind that Indonesia and Morocco have different characteristics in dowry matter, the regulations are worth comparing for. As understood in Islamic marriages, dowry is an important obligation and must be fulfilled by the bridegroom for the bride. Normative Islamic teaching advocates for dowry that is simple and reasonable, but in practice, sometimes dowry becomes expensive and difficult to be given, and thus, causing unfavorable effects. In addition, dowry also has the potentials to be subjected to disputes between husband and wife if not regulated by legislation in details. The author uses a comparative study of law guided by a normative approach through library research. The main source is the statutes of two countries. Analysis technique used is content analysis. As a result, it is found that with different backgrounds of fiqh school in Indonesia and Morroco-one being strongly influenced by Shâfi ' $\bar{\imath}$ school and the other is influenced by Mālikī school-have similar rules on dowry. The only significant difference is that the Māliki School and its legislation in Morocco considers dowry as a marriage pillar. Meanwhile, the Shâfi 'i school and its legislation in Indonesia, even though the dowry is regarded as compulsory, it does not
\end{abstract}

Associate Professor, Sharia Faculty of State Institute of Islamic Studies (IAIN) Pekalongan, 51141, Indonesia, ali.trigiyatno@iainpekalongan.ac.id. 
become a condition or a marriage pillar. Other differences are the definition of dowry, regulation of wife's luggage, lost dowry, defective dowry, introduction of mithil dowry, regulation of dowry disputes before entering the household, and regulation of furniture disputes other than the wife's luggage.

Keywords: Dowry/dowry regulations, legislation, Indonesia, Morocco

\section{INTRODUCTION}

Before the spread of Islam, the tradition of giving a dowry to a bride has already been found in Arabic tradition. However, the dowry at that time was not intended for the prospective wife, but for the father or close male relatives of the prospective wife. This is due to the fact that dowry is considered as compensation for the father who has cared for and raised the girl; the impression that had arisen is that dowry is the price to redeem a woman. The higher the dowry is paid, the more pride the family has. ${ }^{2}$

An understanding exists in all schools of Islamic law that dowry is an obligation that must be fulfilled by the fiancé to the fiancée when they want to get married. The matter of the maximum amount of dowry is general among the Islamic scholars as there is no maximum limit, while in the case of the minimum limit there is a difference in opinions among Islamic jurists. However, Islamic teachings emphasise on the importance of simplicity and relief in terms of the dowry payment. ${ }^{3}$

Normative Islamic teachings focus on relief and ease in terms of dowry giving and are against raising nominal dowry, but practices in different countries or tribes are different. Some countries are known to be inexpensive in terms of dowry payment, but there are certain countries of which in their customs tend to demand high and expensive dowry which could be burdensome for the bridegroom and his family. Even worse, the issue of dowry can be a barrier to the marriage if an agreement, in this case, is not found among them. ${ }^{4}$

2 Halimah B., 'Konsep Mahar (Maskawin) dalam Tafsir Kontemporer', Jurnal adDaulah, vol. 6/2 (2017): 310-330.

3 Sālim bin Abdul Mughn̄̄ ar-Rāfi ‘र̄, Ahkām al-Aḥwāl al-Shakhșiyyah li al-Muslimīn fi al-Gharb (Bayrūt: Dār Ibn Hazm, 2003), 448-457.

4 Mohammad Azeemulkah, 'The evil practice of dowry in India and in the Arab world' in https://timesofindia.indiatimes.com/nri/citizen-journalists/citizenjournalists-reports/mohammad-azeemullah/The-evil-practice-of-dowry-in-Indiaand-in-the-Arab-world/articleshow/19673234.cms, accessed on 30 January 2021. 
It is not surprising that the government of a country regulates dowry legislations, including Indonesian and Moroccan governments. Comparing dowry provisions in Indonesia and Morocco is quite an interesting review to be done. Geographically, the two countries are very far away, with Indonesia being in Southeast Asia while Morocco in northern Africa. Indonesia, of which Muslim community is dominated by Shāfi ' $\overline{1}$ school, is known to be quite lenient and easy in dowry matters. While Morocco, following the Mālikī School based in North Africa, is known to be quite strict or expensive in dowry provisions.

There is a paper comparing the Indonesian and Moroccan law, for example in family law, by Mutia Wardah entitled Hadānah due to Divorce in Family Law in Indonesia and Morocco. This paper discussed the method of comparing the regulations of hadanah in the two countries. In addition to the similarities, there are also significant differences found of which the regulation of hadanah in Morocco is more complete and detailed as well as more progressive than that of the provisions in Indonesia. ${ }^{5}$

Furthermore, there is a thesis written by Muhammad Shobirin entitled $A$ Comparative Study of Applying Dowry in Indonesia and Malaysia. With the comparison method, the authors concluded that there are similarities in dowry regulations of which both are based on Shāfi'i school. However in Malaysia, it is within the authority of 14 states to regulate including determining nominal dowry based on the social status of the spouse. ${ }^{6}$

Subsequently, Nisa Septyarany wrote a dowry comparison between Jordan and Pakistan. The most interesting thing about this article is that when comparing the provisions of the two countries, Pakistan states that the maximum payment limit is no more than 5000 rupees. When these provisions are violated, there is a maximum sentence of 6 months of imprisonment of, a provision that is rarely found in other countries. ${ }^{7}$

In contrary to the mentioned papers, this paper specifically discusses as well as compares dowry regulations in Indonesia and Morocco based on the laws in their respective countries. In terms of dowry regulations in marriage

5 Mutia Wardah, 'Hadhanah Akibat Perceraian dalam Hukum Keluarga di Indonesia dan Maroko', (Thesis, Program of Hukum Keluarga Islam Fakultas Syariah dan Hukum UIN Jakarta, 2018).

6 Muhammad Shobirin, 'Studi Komparasi Penerapan Mahar di Indonesia dan Malaysia', (Postgraduate Thesis, Program of al-Ahwal al-Shakhshiyyah UIN Maulana Malik Ibrahim Malang, 2013).

7 Nia Septyarani, 'Ketentuan Mahar dalam Perkawinan: Studi Komparatif Hukum Keluarga Islam Yordania dan Pakistan,' (Thesis, Department of Islamic Family Law, Faculty of Sharia, State Islamic Institute of Ponorogo 2019). 
law of both countries, some similarities and differences need to be studied among observers of family law. This paper will try to answer the question on similarities and differences in dowry regulations of these two countries. The author uses a comparative study of law guided by a normative approach through library research. The main source is the statutes of the two countries. This paper also uses content analysis as the analysis technique.

\section{REGULATIONS OF DOWRY IN ISLAMIC JURISPRUDENCE}

Dowry is a fiqh term that has quite a lot of synonyms. Ibn Qudamah stated in al-Mughni that there are nine terms used to describe dowry namely al-șadāq, al-ṣadaqah, al-mahr, al-niḥlah, al-farīdah, al-ajru, al-'alā iq, al-'uqru, and al-hiba: ${ }^{8}$

According to Shäfi'iyyah scholars, dowry is something that becomes mandatory with the existence of marriage contract or intercourse (wat $i$ ) or because it damages the honor of women by force. ${ }^{9}$ While in the Mālikī school, dowry is defined as something given to a wife in return for intercourse with her. ${ }^{10}$

Sidi Umar quoted several contemporary scholars who define dowry to be slightly different from that of classic jurisprudence scholars. Badran Abu alAinain Badran, for example, defines a dowry as a property that is the right of a wife because of a marriage contract or because she will be intrinsically copulated. While Muhammad Kamaluddin Imam defines dowry as property required by the Sharia in the form of property that is the right of the wife and the husband's obligations due to a valid contract or valid coitus. Ahmad alGhandur defines dowry as the husband's obligations related to property that must be paid by the husband to his wife because of a contract or intercourse $($ dukhul $){ }^{11}$

One of the matters agreed upon by ulama in terms of dowry is that the dowry must be paid by the fiancé of the fiancée for a marriage. This is based on

\footnotetext{
8 Ibn Qudāmah, al-Mughnī, vol. 8 (Bayrūt: Dār al-Fikr, 1405), 4.

9 Jalāl al-Dīn Muhammad bin Aḥmad al-Maḥallī, Qalyūbī wa 'Umayrah, vol. 3 (Bayrūt: Dār al-Fikr, 2001), 275.

10 Wahbah al-Zuhaylī, al-Fiqh al-Islāmī wa Adillatuh, vol. 9 (Dimashq: Dār al-Fikr, n.d.), 237.

11 As quoted 'Umar Sid̄̄, 'al-Ḥimāyah al-Qānūniyah li Ḥaqq al-Zawjah fi al-Ṣadāq,' Majallah al-Ijtihād li al-Dirāsat al-Qānūniyyah wa al-Iqtișādiyah, vol. 8/2 (2019): 56-68.
} 
the Quran, Sunnah, and ijmā' 'ulamā'. In this case, Wahbah al-Zuhaylī writes in al-Fiqh al-Islāmī wa Adillatuh:

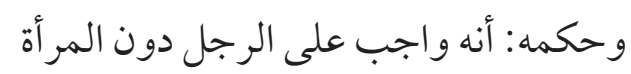

"The dowry law is mandatory for the husband, not for the wife." 12

Concerning the amount of dowries, Ibn Rushd explained, Islamic scholars agreed that there is no maximum limit in the payment of dowries, while the minimum limit is what they differ in views. Imam al-Shāfi ' $\overline{1}$, Aḥmad, Ishạq, Abu Thawr, and Medina Fuqaha said that there is no minimum limit in the payment of dowry and anything that can be used as a price for something else may be used for the dowry. This opinion is also shared by Ibn Wahb from Mālikī school. ${ }^{13}$

While a group of scholars believes that dowry requires a minimum amount, this group is then divided into two opinions, namely the Mālikī schools and their followers as well as Hanafĩ schools and their followers. Imam Mālikī suggests that the minimum dowry is a quarter of a gold dinar, weighing three silver dirhams, or an item that is equivalent to three dirhams, according to a well-known history. According to another narration, it is equal to one of the minimum sizes above. Meanwhile, according to Imam Abu Hanifah, the dowry should be at least ten (10) dirhams; and according to another narration, it is five (5) dirhams; while in another narration forty (40) dirhams is mentioned. ${ }^{14}$

Even though there is no highest limit in terms of dowry, Islam does not encourage dowry to be too high until it burdens the prospective husband and family. Sayyid Sābiq explained that Islam provides a chance as wide as possible so that more men and women are bounded by the fabric of marriage so that each may be engaged and benefit from lawful sexual relations. This goal cannot be achieved unless the road is easy, so that poor people who cannot afford to pay large amounts of money can do it as well. ${ }^{15}$

Indeed, Islamic teachings emphasise simplicity and ease in terms of dowry giving, so as not to overly burden the grooms. This is stated in al-Maws $\bar{u}$ ' $a h$ al-Fiqhiyyah al-Kuwaytiyyah as follows:

\footnotetext{
12 Wahbah al-Zuhaylī, al-Fiqh al-Islāmī wa Adillatuh, 238.

13 Ibn Rushd, Bidāyah al-Mujtahid wa Nihāyah al-Muqtașid (Miṣr: Mațba'ah Mustafā al-Bābī al-Halābī wa Awlāduhu, 1395). See also Muhammad Mustafāā Shiblī, Ahkām al-Usrah fì al-Islām (Bayrūt: Dār al-Jam‘iyyah, 1403), 365-369.

14 Ibn Rushd, Bidāyah al-Mujtahid wa Nihāyah al-Muqtașid. See also Muhammad Musțafā Shiblī, Ahkām al-Usrah fì al-Islām, 365-369.

15 Sayyid Sābiq, Fiqh al-Sunnah, vol. 2 (Bayrūt: Dār al-Fikr, 1412), 138.
} 


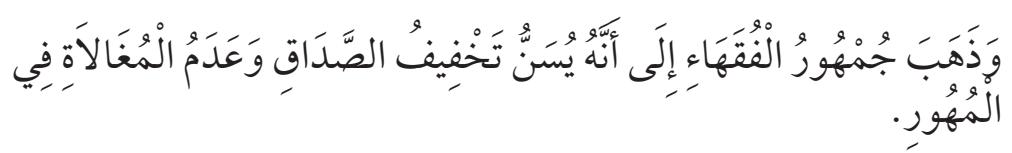

"The majority of fuqaha argues that it is recommended to ease the dowry and not cause burden in dowry matters." 16

More specifically, Imam Shāfi‘‘ explains in al-Umm as follows:

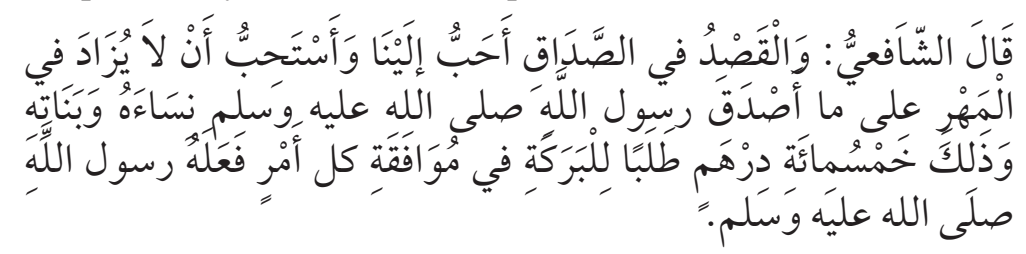

"Al-Shäfi 'ì said: Being modest in matters of dowry I prefer, and I like the dowry no more than what the Messenger of Allāh had given to his wives and daughters i.e., 500 dirhams to get blessings in any affairs that were under the Prophet's deeds." 17

However, there are differences regarding the status of dowry in marriage, whether it is a condition or a pillar. In the Mālikī school, dowry is a pillar of marriage, as informed by 'Abd al-Raḥmān al-Jazirī as follows:

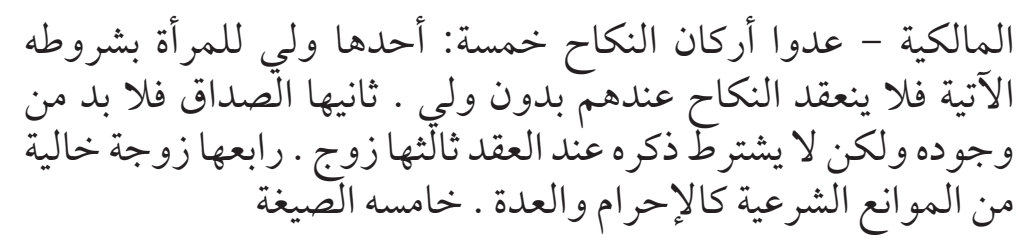

"Mālikiyah determines the five pillars of marriage, namely, wali, sadā, although not required to be called when the contract takes place, a wife who has no obstacle to marrying as if she is ihram and being iddah, the fifth is sighat or ìjāb qabūl." 18

While the Shāfi'i school, as informed by 'Abd al-Raḥmān al-Jazirī, stipulates the five pillars of marriage but there is a slight difference. Shāfi 'iyyah believes that there are five marriage pillars, i.e., husband and wife, guardian, two witnesses, and sighat. ${ }^{19}$

\footnotetext{
16 Wuzārah al-Awqāf wa ash-Shu'ūn al-Islāmiyyah Kuwayt, al-Mawsū'ah alFiqhiyyah al-Kuwaytiyyah, Vol. 38 (Mișr: Mațabi' Dār al-Șafwah, 1427), 239.

17 Al-Shāfi'‘̄, al-Umm, vol. 5 (Bayrūt: Dār al-Ma'rifah, 1393), 58.

18 'Abd al-Raḥmān al-Jazirī, Kitāb al-Fiqh 'alā Madhāhib al-Arba'ah (Bayrūt: Dār al-Kutub al-'Ilmiyyah, 2004), 712.

19 'Abd al-Raḥmān al-Jazirī, Kitāb al-Fiqh 'alā Madhāhib al-Arba'ah, vol. 4, 712.
} 
From this brief information, it is clear that there are differences in the position of dowry and witnesses in a marriage. Dowry is a pillar in the Mālikī school but not in Shāfi' $\overline{1}$, whereas having witnesses is a pillar in the Shāfi 'ํํ but not Mālikī.

\section{Regulations of Dowry in Indonesia}

As mentioned earlier, the majority of Muslims in Indonesia adhere to the Shāfi' $\overline{1}$ school. In terms of dowry, Shāfi' $\overline{1}$ school is relatively easy and not bounded by certain rules. No minimum and maximum limits are specified in Indonesia in regards to dowry payment. The rule that is used in this school is that everything that is legally sold or has a value can then legally be made into a dowry. And those who have no value cannot be made a dowry as long as they do not reach limits that cannot be assessed. If a contract is made with a dowry in the form of something that cannot be valued such as seeds and gravel, the agreement is broken, and he must give mithil dowry. This opinion was chosen and favored by Wahbah al-Zuhaylī. ${ }^{20}$

Regarding dowry regulations in Indonesia, Law No. 1 of 1974 which concerns marriage, however, also includes explanation about dowry in it. The dowry rules are somewhat detailed in Inpres (presidential instruction) number 1 of 1991 concerning the Dissemination of Compilation of Islamic Law abbreviated as KHI. Nine articles regulate dowry in KHI which represents the majority of scholars. ${ }^{21}$

KHI consists of three books, 29 chapters, and 229 articles. The first book of marriage law contains 19 chapters and 170 articles while the second book of inheritance law includes 6 chapters and 44 articles. Finally, the third book of law on waqf covers 5 chapters and 15 articles. $^{22}$

The KHI's position in the Indonesian national legal system is a positive Islamic law in implementing laws and regulations that have a higher position and eventually become a reference. Concerning the judicial element, KHI is used as a guideline in the settlement of cases submitted to the court within the Religious court environment. This is based on the arrangement of KHI being

20 Wahbah al-Zuhaylī, al-Fiqh al-Islāmī wa Adillatuh, vol. 9, 243.

21 Muhammad Shobirin, 'Studi Komparasi Penerapan Mahar di Indonesia dan Malaysia,' 56.

22 See Inpres No. 1 Tahun 1991; Muji Mulia, 'Pembaharuan Hukum Islam di Indonesia: Analisis Historis tentang Kompilasi Hukum Islam,' Islam Futura, vol. 7/1 (2008): 64-85 
carried out to fill the substantial legal vacuum that is used as a reference in the settlement of the proposed case. ${ }^{23}$

The main objective of KHI is to 'make positive' Islamic law in Indonesia. To positively and systematically promoting Islamic law in the book of the law, there are several main objectives should be achieved and addressed:

1) Complete the pillars of religious justice;

2) Equate the perception of the application of the law;

3) Clear up the understanding of private affairs;

4) Speed up the process taqrīb bain al-ummah. ${ }^{24}$

Furthermore, the author will express dowry regulations in KHI as follows:

Related to the meaning of dowry, KHI defines dowry as follows:

"Article 1 letter d, Dowry is a gift from a bridegroom to a bride in the form of goods, money, or services that are not contrary to Islamic law." 25

The definition put forward by KHI seems a rather broad and general one because whatever is given by the bridegroom to the bride in the form of goods, money, or services is called dowry on the condition that it is not contrary to Islamic law.

In general, the Javanese as the majority ethnic in Indonesia, where about 40 percent of the Indonesian population is of Javanese ethnicity, recognises the distinction between hantaran, seserahan, and dowry. Hantaran is a gift brought by the groom's family when proposing to a prospective wife. Hantaran is not mandatory, but it is encouraged. After the proposal is received before the marriage contract, the male family will usually give gifts in the form of clothes, jewelry, foodstuffs, money, and others. It is also not a necessity although it is usually done. Seserahan is given according to the ability of the male family and usually, the woman's family also does not determine that only based on merit. Furthermore, in the contract, the husband must prepare a dowry as an obligation. This dowry on the island of Java is often only in the form of a set

23 Asriati, 'Pembaruan Hukum Islam dalam Terapan dan Perundang-Undangan di Indonesia', Jurnal Hukum Diktum, vol. 10/1, (2012): 23-39.

24 Mochammad Muslim, 'Pengaruh Konfigurasi Politik Hukum Orde Baru terhadap Kompilasi Hukum Islam (KHI) di Indonesia', al-Daulah, vol. 4/1 (2014): 220242.

25 Article 1 letter d Presidential Instruction Number 1 of 1991about Dissemination of Islamic Law Compilations. 
of prayer tools containing a prayer mat, prayer beads, and a Koran Mushaf worth around 300 thousand rupiah (20 USD) to 1 million rupiahs (68 USD). Sometimes a set of prayer tools are added with 2 grams to 50 grams of gold jewelry. ${ }^{26}$

Regarding the position of the dowry, it is considered compulsorily as KHI stipulated, in Article 30.

"The bridegroom must pay a dowry to the bride of which number, shape, and type are agreed by both parties. " 27

Even though dowry is compulsory, KHI emphasises it is not a pillar or legal condition of a marriage.

Furthermore, KHI spells out that the dowry is held based on the principle of simplicity and convenience. In the case of dowry, Indonesian law also adheres to the principle of simplicity and eas as recommended in fiqh books and the school Shāfi'‘̄ in particular as outlined in Article 31:

"Determination of dowry based on simplicity and ease recommended by Islamic teachings. " 28

However, in practice, considering that there are 1340 tribes in Indonesia, each having different customs, it is found that there are three categories of dowry namely the expensive, the medium, and the simple dowry. The high cost of marriage often has negative effects such as marriage delays and even marriage cancellations due to the large demand of fees from the female's family that the male family cannot afford. Moreover, due to the high cost, couples who love each other might finally choose to elope (kawin lari). ${ }^{29}$ Seven tribes that are known to require expensive dowry for marriages are the Banjar tribe in South Kalimantan, the Bugis tribe in South Sulawesi, the Minang tribe

26 https://www.merdeka.com/gaya/hantaran-seserahan-dan-mahar-apa-bedanya. html?page=3, accessed March 30, 2021.

27 Article 30 Presidential Instruction Number 1 of 1991about Dissemination of Islamic Law Compilations. See also Amiur Nuruddin \& Azhari Akmal Tarigan, Hukum Perdata Islam di Indonesia (Jakarta: Kencana, 2004), 66.

28 Ahmad Rofiq, Hukum Perdata Islam di Indonesia (Depok: Rajawali Press, 2017), 85 .

29 Kawin lari (elopement) is an act of escaping a woman without permission, which aims to live together or get married. It can also mean the kidnapping of a minor with her consent, but not liked by her parents. This can also be interpreted as kidnapping the bride, either through tactics, coercion or threats. In Indonesia, this habit still exists in several places, such as in Lampung, Bali, North Sumatra, etc. https://id.wikipedia.org/wiki/Kawin_lari\#, accessed April 6, 2021. 
in West Sumatra, the Batak tribe in North Sumatra, the Nias tribe in North Sumatra, the Sasak tribe in West Nusa Tenggara, and the Balinese tribe in Bali. ${ }^{30}$ The determination of the type and amount of dowry in the Muslim Banjar community can be tough and dramatic. The process of bargaining for the amount of a dowry (called in Banjarese as bapintaan) usually occurs during the engagement process. Many cases of engagement are terminated simply because a dowry agreement cannot be reached. In certain societies, the type and amount of dowry can be determined unilaterally by the woman's family. ${ }^{31}$

The simplicity and ease of dowry in writer's observations are still prevalent among Javanese tribes who live mainly in East Java, Central Java, and Yogyakarta Special Region. You could say that the dowry in this area is in the medium category and could be cheap. Not infrequently, if the family of the prospective husband is less fortunate, the wife's family willingly helps lower down the dowry or even exempts the cost of the marriage as long as their children are compatible and happy with the marriage. The author also does not see or hear any bargaining payment of dowry in this area, because this is not considered appropriate according to the Javanese. ${ }^{32}$

Next, KHI regulates the ownership status of the dowry and the technicalities for the delivery.

Article 32 KHI stipulates: Mahar is given directly to the bride and it is her right. ${ }^{33}$

Indeed, in addition to dowry, indigenous communities also recognise gifts in other forms and designations that are generally given by the husband to help the preparation of the wedding. If it is called a special dowry for the bride, those submitted in other forms can be used to finance the wedding or be given to the bride's family as a gift.

It is recommended for the dowry to be paid in cash, not owed, although the dowry is allowed to be owed or paid either in part or in full with the approval of the bride. If it is owed, it is considered as the husband's debt to his wife. This rule is contained in Article $33 \mathrm{KHI}$ which reads:

\footnotetext{
30 https://id.theasianparent.com/adat-pernikahan, accessed April 8, 2021.

31 Noryamin Aini, 'Tradisi Mahar di Ranah Lokalitas Umat Islam: Mahar dan Struktur Sosial di Masyarakat Muslim Indonesia,' Ahkam, vol. 14/1 (2014): 21.

32 https://id.wikipedia.org/wiki/Suku_bangsa_di_Indonesia\#, accessed April 5, 2021.

33 Ahmad Rofiq, Hukum Perdata Islam di Indonesia, 87.
} 
"(1) Submission of the dowry is done in cash."

"(2) If the bride and groom agree, the transfer of the bride's price may be deferred in whole or in part. Dowry which has not been paid for is the debt of the bridegroom." 34

In the writer's observation in the Javanese community, it is rare for a dowry to be owed, because usually, the PPN (Pegawai Pencatat Nikah/Marriage Registration Officer) will ask about the dowry and whether or not it has been paid before the contract of marriage takes place. Generally, what is mentioned in the contract is a dowry that is light and simple, such as a set of prayer tools, which only worth hundreds of thousands of rupiahs, so there are hardly any cases of owed dowry.

Regarding the status of a dowry, KHI explicitly states that a dowry is not a pillar of marriage just as stated by Shāfi '` 1 school as well. If there is negligence or error in the mention of the type and number of the dowry, it does not cause the cancellation of the marriage. If the groom is still in debt of the dowry, it also does not reduce the legality of the marriage. This provision is explicitly stated in article $34 \mathrm{KHI}$.

"(1) Obligation to surrender the dowry does not constitute a pillar in marriage."

"(2) Failure to mention the type and amount of dowry at the time of the marriage contract, does not cause the cancellation of the marriage. Likewise in a state of still dowry payable, it does not reduce the validity of the marriage." 35

While, in the situation of divorce before $d u k h \bar{u} l$ (sexual intercourse), the husband must pay half of what is determined when the contract takes place. Meanwhile, if the husband dies before sexual intercourse (qabla al-dukhül) but the dowry amount has not been determined, the husband must pay mithil dowry. This rule is stipulated in article 35 of KHI which reads.

"(1) A husband who divorces his wife, qabla al-dukhūl is required to pay half the dowry that has been determined in the marriage contract."

34 Amir Syarifuddin, Hukum Perkawinan Islam di Indonesia (Jakarta: Kencana, 2014), 98.

35 Ahmad Rofiq, Hukum Perdata Islam di Indonesia, 87. 
"(2) If the husband dies, or qabla al-dukhul, but the dowry amount has not been determined, the husband is obliged to pay mithil dowry." ${ }^{36}$

KHI also anticipates the situation of loss of dowry before being handed over to the bride. If this happens, the dowry can be replaced with other goods that have similar shapes and types; or it can be replaced with other goods of the same value or it can also be replaced with the money of the same value or as the lost dowry. This is regulated in Article 36 KHI.

"If the dowry is lost before being delivered, the dowry can be replaced with other goods of the same shape and type or with other goods of the same value or with money worth the price of the lost dowry goods." 37

Meanwhile, the relation between humans is not always harmonious. Sometimes disputes happen, and dowry determination is not exempted. To anticipate it, the Religious Court has been established as a place to reach settlement among parties in connection to certain civil cases concerning family law including dispute regarding dowry. This provision is contained in article $37 \mathrm{KHI}$ which reads: ${ }^{38}$

"If there is a difference of opinion regarding the type and value of the stipulated dowry, the settlement shall be submitted to the Religious Court." 39

In the writer's observation, it is rare for dowry cases to be the object of dispute in religious courts. This is because in Indonesia, it has rarely happened considering the fact that it is usually resolved amicably through consensus agreement.

There is also the possibility of the given dowry containing defects or is damaged, and if the bride does not mind receiving it unconditionally in this situation, the dowry is considered paid. While if the wife refuses to accept the dowry because of the defect, the husband must replace it with another dowry

36 Harijah Damis, 'Konsep Mahar dalam Perspektif Fikih dan Perundang-Undangan Kajian Putusan Nomor 23 K/AG/2012', Jurnal Yudisial, vol. 9/1 (2016): 19-35. See also M.A. Tihami \& Sohari Sahrani, Fikih Munakahat: Kajian Fikih Nikah Lengkap (Depok: Rajawali Pers, 2018), 54-55.

37 Ahmad Rofiq, Hukum Perdata Islam di Indonesia, 88.

38 Harijah Damis, 'Konsep Mahar dalam Perspektif Fikih dan Perundang-Undangan Kajian Putusan Nomor 23 K/AG/2012,' 19-35.

39 Amir Syarifuddin, Hukum Perkawinan Islam di Indonesia, 99. 
that is not defective. As long as the substitute has not been submitted, the dowry is still considered unpaid. This is stipulated through article 38 of KHI.

"(1) If the dowry delivered contains defects or is deficient, but the bride is still willing to accept it unconditionally, the dowry is considered paid off."

"(2) If the wife refuses to accept the dowry due to a defect, the husband must replace it with another dowry that is not defective. As long as the substitute has not been submitted, the dowry is still considered unpaid." 40

Thus, a brief explanation of dowry provisions in Indonesian Law is as regulated in the Compilation of Islamic Law through Presidential Instruction Number 1 of 1991 articles 30 to $38 .{ }^{41}$

The purpose and objectives of dowry regulations in KHI are as follows:

Firstly, to bring order to the dowry matter; secondly, to establish legal certainty that dowry is not a pillar of marriage; thirdly, to establish dowry ethics on the principle of simplicity and ease and not based on the principles of economics, status, and prestige; fourth, to standardise juridical and dowry ethics concepts in fostering the same order and perception among the community and law enforcement officers. ${ }^{42}$

\section{DOWRY REGULATION IN MOROCCO ${ }^{43}$}

To carry out marriages in Morocco requires several things as stipulated in article 13 Mudawwanah al-Usrah. First, the legal competence of the bride and groom; second, they must not agree to abort the dowry; third, marriage guardian if desired; fourth, it is listened to and recorded by two public notaries at the ijab qabul spoken by the bride and groom; fifth, there are no legal impediments. Article 13:

40 Harijah Damis, 'Konsep Mahar dalam Perspektif Fikih dan Perundang-Undangan Kajian Putusan Nomor 23 K/AG/2012,' 19-35.

41 Mardani, Hukum Keluarga Islam di Indonesia (Jakarta: Kencana, 2016), 49-50.

42 Mardani, Hukum Keluarga Islam di Indonesia, 51.

43 The writer is fortunate enough to have visited Morocco for approximately two weeks from 22 November 2013 to 3 December 2013. The writer has visited several historical cities such as Fes, Meknes, Marrakech, Casablanca, Rabat and Tangier. Explanations and narrations from several Indonesian lecturers and students who studied there about marriage law were sufficient to add information to the author. 
"The conditions required to contract marriage are:

1- The legal capacity of both spouses to marry;

2- No intention or agreement to cancel the dowry;

3- A marital guardian, if required;

4- The hearing and notarized statement by two adouls (public notaries) of the offer and acceptance pronounced by the two spouses;

5- The absence of any legal impediments." 44

As seen in Article 13 paragraph 2, marriage requires no intention or agreement to cancel or eliminate dowry. This shows that dowry is a principle in the marriage law in Morocco. Even if the bride and groom, for example, agree to abolish the dowry, this is still not permitted by law.

Furthermore, dowry regulations in Morocco are found in the new Mudawwanah (family Code) or the full name, Mudawwanah al-Ahwāl alShakhșiyyah al-Jadìdah fì al-Maghrīb which was ratified on February 3, 2004. The new Mudawwanah contains 400 articles. Compared to the abolished Mudawwanah, which was made in 1957, it only contained 300 articles hence, there is a significant addition of 100 articles. ${ }^{45}$

The dowry regulation in Morocco is found in Mudawwanah al-Usrah 2004 from articles 26 to 34. These articles are further explained by Muhammad al-Shāfi' $\overline{1}$, Lecturer in the Faculty of Law in Marrakech in his book alZawāj fi Mudawwanah al-Usrah. Meanwhile, the official explanation from Mudawwanah al-Usrah was put forward by the Ministry of Justice entitled Dalīl 'Amalì li Mudawwanah al-Usrah. Regulations and explanations for dowry issues are discussed from pages 32 to $35 .{ }^{46}$

44 Muhammad al-Farujī, Mudawwanah al-Usrah (Dār al-Bayḍa': Maṭba'ah al-Najāḥ al-Jadīdah, 2012), 17.

45 The history of renewal and the debate around Mudawwanah al-Usrah. See Fatimah Harrak, 'The History and Significance of The New Moroccan Family Code', can be downloaded from the site http://www.cics.northwestern.edu/documents/ workingpapers/ISITA_09-002_Harrak.pdf, accessed on January 22, 2021.

46 Wuzārah al-'Adl, Dal̄̄l 'Amal̄̄ li Mudawwanah al-Usrah (Rabaṭ: Jam'iyyah alMa'lūmah al-Qānūniyah al-Qạ̣a'iyyah, 2004). 
Furthermore, the author will describe several provisions in the regulation of dowries in Morocco by referring to the provisions of Mudawwanal al-Usrah, starting from articles 26 to 34 by quoting Muhammad al-Shāfi' 'i's explanation and the official explanation from the ministry of law.

In terms of the definition of a dowry, dowry or mehr is defined in Mudawwanah al-Usrah chapter 26 as:

"The dowry is that which the husband gives to his wife as an expression of his desire to marry her and to build a stable family based on affection and good amicable relations between husband and wife. Its legitimacy is based on its moral and symbolic value rather than its material value." 47

This definition is arguably more complete and emphasises the purpose of giving a dowry which is no longer associated with the marriage contract and intercourse as mentioned by many of the pre-defined books of Mālikī schools. This definition is also more comprehensive and complete than the definition of dowry in KHI Indonesia.

Dowry is one of the stipulations for marriage in Morocco that needs to be said or mentioned in the contract, but sometimes in practice, it is not mentioned in the contract. Under these conditions, marriage remains valid and is called marriage tafwidh. If a dispute arises between husband and wife after marriage (intercourse) about the number of dowries, the court will decide on how much dowry is to be paid, based on the social background of both parties. ${ }^{48}$ This can be understood from the provision of article 27.

"The dowry amount is specified upon the conclusion of the marriage contract, and in the event of it it is not specified, the marriage is deemed one of "entrustment." If the husband and wife do not agree on the amount of dowry during the marriage of "entrustment", the court shall determine its amount by taking into consideration the social background of both the husband and wife." 49

47 Wuzārah al-'Adl, Dalīl 'Amalī li Mudawwanah al-Usrah, 32. See also Muhammad al-Farujī, Mudawwanah al-Usrah, 19. See also Muhammad al-Shāfi‘ī, Qānun al-Usrah fì Duwal al-Maghrīb al-'Arabī (Marakesh: Mațba'ah Waraqah alWațaniyyah, 2009), 274.

48 Wuzārah al-'Adl, Dalīl 'Amalī li Mudawwanah al-Usrah, 32.

49 Wuzārah al-'Adl, Dal̄̄l 'Amalī li Mudawwanah al-Usrah, 32. 
Regarding the form and the simplicity of dowry, the basis of dowry is a symbolic value, of which what the law demands is not to be overly demanding on dowry value. Also, a dowry does not have to be in the form of money, but everything that has value according to Shariah is a valid dowry.

Article 28 states:

"Anything that constitutes a source of legal commitment can
serve as a dowry, and the dowry should be modest." 50

In terms of simplicity, there are similarities between KHI and Mudawanah, as well as in the books of fiqh, although in practice, there are those who obey and those who do not in the communities of the two countries. In Indonesia and Morocco, there are variations in the practice of giving dowry. Certain tribes demand a high dowry, while others are medium. In Morocco, the amount of the dowry varies greatly between ethnic groups (Arabs, Amazigh, and Hassanya), geographical origin, and social strata. ${ }^{51}$

However, in the context of Morocco, the ethnicity of the couple seems to be the most important factor in determining the price of a bride and groom. In Arab population, the average price for a bride is around MAD 5,000, of which from 1,000-3,000 MAD is considered underprivileged families and from 10,000-20,000 MAD is for wealthier families. In some areas and social strata, the dowry is symbolic, such as a louis d'or (gold coin) in the Arab upperclass family in the city of Fez. Among the Amazigh population of northern Morocco, the dowry is generally higher than that of the Arab population. While the price of a bride and groom in low-income families is around 10,000 MAD, in principle, there is no maximum limit on well-off families. ${ }^{52}$ According to Mirr Hosseini, the value and composition of sadaq vary according to social class and regional customs. Some regions such as Oujda and Fez, in the center of the country, are renowned for their traditions of high sadaq. ${ }^{53}$

The position of the dowry which is so important in Morocco can result in the marriage being postponed or even cancelled if the family of the man and the woman does not reach an agreement on the dowry. ${ }^{54}$

50 Muhammad al-Farujī, Mudawwanah al-Usrah, 20. See also Muhammad alShāfi‘‘̄, al-Zawāj fì Mudawwanah al-Usrah, 139.

51 Anonym, Report Morocco: Marriage and Divorce - Legal and Cultural Aspects, LANDINFO, 21 April 2017, 19.

52 Anonym, Report Morocco: Marriage and Divorce - Legal and Cultural Aspects, 19-20.

53 Ziba Mir-Hosseini, Marriage on trial, (New York: St Martin's Press, 1997), 97.

${ }_{54}$ https://en.wikipedia.org/wiki/Dowry\#Morocco, accessed April 3, 2021. 
Regarding dowry ownership, Article 29 Mudawwanah explains that:

"The dowry is the woman's property to use as she wishes, and the husband has no right to ask her for furniture or anything else in exchange for the dowry he gave her." 55

Dowry either in the form of goods or little or a lot of money is the full property of the wife where she may use it as she wishes. The husband has no right to ask for it back or order the wife to buy household furniture or for any reason without his wife's permission. ${ }^{56}$

Regarding the delivery of the dowry, Mudawawanah allows immediate or deferred payment. Article 30 says:

"The husband and wife may agree on the immediate or deferred payment of the dowry within a fixed deadline, be it for the entire amount or part of it." 57

Moroccan law allows a husband and wife to agree on the payment of the dowry either in cash, and either all or partially during marriage contract, or to postpone it all or partially until the agreed time limit. This does not affect the legality of their marriage. ${ }^{58}$

Regarding when the dowry must be paid, article 31 stipulates:

"The dowry is paid on the fixed deadline. The wife may ask for the payment of the dowry before starting conjugal life. When conjugal life commences before payment of the dowry, it becomes a debt on the husband." 59

The husband is obliged to pay the dowry on the agreed time when the contract expires. The wife has the right to demand the settlement of the dowry before starting the life as husband and wife, but if the married life has started and the dowry has not been paid, the dowry is considered as the husband's

55 Wuzārah al-'Adl, Dalīl 'Amalī li Mudawwanah al-Usrah, 33. See also Muhammad al-Shāfi‘̄ì, al-Zawāj fì Mudawwanah al-Usrah, 139.

56 Wuzārah al-'Adl, Dal̄̄l 'Amalī li Mudawwanah al-Usrah, 33.

57 Muhammad al-Farujīi, Mudawwanah al-Usrah, 20; Muhammad al-Shāfi‘ī, alZawāj fì Mudawwanah al-Usrah, 142.

58 Wuzārah al-'Adl, Dalīl 'Amalī li Mudawwanah al-Usrah, 33.

59 Muhammad al-Farujī, Mudawwanah al-Usrah, 20; Wuzārah al-'Adl, Dalīl 'Amalī li Mudawwanah al-Usrah, 33. 
debt. ${ }^{60}$ The terms of whether the dowry is paid in full, half, or forfeited, Article 32 states:

"The wife's right to the totality of the dowry vests with the consummation of the marriage or if she dies before the husband does. She has the right to half of the dowry if divorce occurs before the marriage is consummated. She has no right to the dowry before the marriage is consummated:

1- When the marriage contract is nullified;

2- When the marriage contract is rejected because of a defect in the wife or because of a defect in the husband;

3- When divorce occurs in a marriage of tafwidh." 61

The provisions in this article are quite clear hence, there is no official explanation given. ${ }^{62}$ To anticipate a dispute over a dowry, Article 33 explains:

"When the payment of the dowry before the marriage is consummated in dispute, the wife's declaration takes precedence over the husband's. When the payment of the deferred dowry is in dispute, the husband must prove that he has paid it. Mahar does not expire." 63

To anticipate a dowry dispute, when there is a dispute on dowry payment before marriage and sexual intercourse, the wife's statement or confession takes precedence over the husband's statement, given that the dowry is usually paid at the beginning of the marriage. If the deferred dowry payment becomes a dispute, the husband must prove that he has paid it. In this case, it is emphasised in the law that the dowry never expires. This means that under any circumstances, the dowry will become the right of the wife and the husband is obliged to fulfill it, the dowry is still owed even the husband dies, it must be taken from the inheritance to pay it. ${ }^{64}$

${ }_{60} \quad$ Wuzārah al-'Adl, Dalīl 'Amalī li Mudawwanah al-Usrah, 33.

61 Muhammad al-Farujī, Mudawwanah al-Usrah, 20; Muhammad al-Shāfi'‘̄, alZawāj fì Mudawwanah al-Usrah, 143. Muhammad al-Shāfi' 'ì, Qānun al-Usrah fì Duwal al-Maghrīb al-'Arabī, 275.

62 Wuzārah al-'Adl, Dalīl 'Amalī li Mudawwanah al-Usrah, 34.

63 Wuzārah al-'Adl, Dalīl 'Amalī li Mudawwanah al-Usrah, 34. Muhammad alShāfi'‘̄, Qānun al-Usrah fì Duwal al-Maghrīb al- 'Arabī, 275.

64 Wuzārah al-'Adl, Dalīl 'Amalī li Mudawwanah al-Usrah, 34-35. 
Mudawwanah also explains wives' original property. However, if neither the husband nor the wife presents any evidence, the husband under oath will have to claim those items that men habitually use, and the wife under oath will have to claim those items that women habitually use. Objects commonly used by men and women will be, upon the sworn word of both of the spouses, shared between them when neither of them renounces his or her oath. ${ }^{65}$

This article regulates that household items which are taken by the wife from her family in the form of mattresses and household furniture into the household belong to his wife. If there is a dispute between husband and wife on household furniture other than those brought by the wife, the settlement is based on the applicable evidentiary law in court in general. If each husband and wife is unable to prove whom the goods belong to, then in this case there are three possibilities. First, if it is common in the community that goods come from a husband, then the husband has the right to have it after taking an oath. Second, if according to the customs the goods are taken by the wife, then the wife has the right to have it after taking an oath. If the object in the custom can come from both husband and wife at the same time, then when the both of them take oath, the object is divided equally. This provision applies if the indictment does not find a strong indication that corroborates one of the claims of the husband or wife, the court will determine the law in this way. ${ }^{66}$

This explanation is taken from the provisions of Article 34 which reads:

"All possessions the wife brings with her to the marriage including furniture and accompanying items are her property. When disputes arise concerning the remaining household furnishings, the matter is decided according to general rules of evidence." 67

Slightly different from the law in Morocco, there are two kinds of assets in a marriage in Indonesia. The first is called gawan property or original property. Original assets are assets that have been owned or carried by each husband and wife before marriage. Original assets remain fully owned by each of them without interference from the partner unless a different agreement is made. Household furniture that is brought by the husband, for example, remains as the property of the husband, while the furniture that is brought by the wife still belongs to the wife. The second is called joint property which in customary

65 Wuzārah al-‘Adl, Dalīl 'Amalī li Mudawwanah al-Usrah, 35; Muḥammad alShāfi'‘̄, Qānun al-Usrah fì Duwal al-Maghrīb al- 'Arabī, 275.

66 Wuzārah al-'Adl, Dalīl 'Amalī li Mudawwanah al-Usrah, 35-36.

${ }_{67}$ Muhammad al-Farujī, Mudawwanah al-Usrah, 20; Muḥammad al-Shāfi ‘'̄i, Qānun al-Usrah fì Duwal al-Maghrīb al- 'Arabī, 275. 
law is called the gono-gini property. Joint assets are deemed to occur after the couple is married unless another agreement is made. Joint property is owned by half or 50 percent each if the spouse divorces or one of them dies. In the matter of marital property, it appears that the law in Indonesia upholds the equal rights and positions of husband and wife. ${ }^{68}$

From the brief description above, a table of similarities and differences in dowry regulations in Indonesia and Morocco can be made as follows.

Table 1: The Similarities

\begin{tabular}{|c|c|c|c|}
\hline No. & Issues & Indonesia & Morocco \\
\hline 1. & $\begin{array}{l}\text { Dowry must be paid by a } \\
\text { husband }\end{array}$ & Article 30 & Article 31 \\
\hline 2. & Object of dowry & $\begin{array}{l}\text { Dowry objects can be in the } \\
\text { form of goods, money, services } \\
\text { that are not contrary to Islamic } \\
\text { law (Article 1.d) }\end{array}$ & $\begin{array}{l}\text { Anything recognized as having } \\
\text { legal value is considered a dow- } \\
\text { ry (article } 28 \text { ) }\end{array}$ \\
\hline 3. & $\begin{array}{l}\text { Simplicity and ease of } \\
\text { dowry }\end{array}$ & Article 31 & Article 28 \\
\hline 4. & $\begin{array}{l}\text { Dowry owned fully by } \\
\text { wifes }\end{array}$ & Article 32 & Article 29 \\
\hline 5. & $\begin{array}{l}\text { It may be cash or credit in } \\
\text { dowry payments and does } \\
\text { not affect the validity of the } \\
\text { marriage }\end{array}$ & Article 33 & Article 30 \\
\hline 6. & $\begin{array}{l}\text { Husbands who divorce their } \\
\text { wives before intercourse } \\
\text { (qabla dukhul) are obliged } \\
\text { to pay half the dowry stipu- } \\
\text { lated in the marriage con- } \\
\text { tract. }\end{array}$ & Article 35 paragraph 1 & Article 32 \\
\hline 7. & $\begin{array}{l}\text { Settlement if there is a dis- } \\
\text { pute submitted to the Court. }\end{array}$ & Article 37 & Article 27 \\
\hline 8. & $\begin{array}{l}\text { Regulation of loss of wife's } \\
\text { dowry under certain condi- } \\
\text { tions }\end{array}$ & No affirmation & Article 32 \\
\hline
\end{tabular}

68 Suparman Usman \& Yusuf Somawinata, Fiqh Mawaris (Jakarta: Gaya media Pratama, 2002), 45-46. 
Table 2: The Differences

\begin{tabular}{ccl}
\hline No. & \multicolumn{1}{c}{ Issues } & \multicolumn{1}{c}{ Indonesia } \\
\hline 1. & Definition of Dowry & $\begin{array}{l}\text { Dowry is a gift from a bride- } \\
\text { groom to a bride, in the form of } \\
\text { goods, money, or services that are } \\
\text { not contrary to Islamic law. (Ar- } \\
\text { ticle 1 letter d) }\end{array}$
\end{tabular}

2. Dowry is not a pillar of Article 34 paragraph 1 marriage

3. Regulate wife's luggage.

No regulation

4. Lost Dowry

If the dowry is lost before being handed over, the dowry can be replaced with another same item

the shape and type, or other goods of the same value or money of the same value at the price of the missing dowry goods. Article 36

5. Defective Dowry

1) If the dowry delivered con- No regulation tains defects or is deficient, but the bride is still willing to accept it unconditionally, the delivery of the dowry is considered paid.

2) If the wife refuses to accept the dowry because of a defect, the husband must replace it with another dowry that is not defective. As long as the replacement has not been delivered, the dowry is still considered not yet paid. Article 38

6. $\quad$ Introducing Mithil Dowry

If the husband dies qabla al- Not mentioning mithil Dowry $d u k h \bar{u} l$ but the dowry amount has not been determined, then the husband is obliged to pay mithil Dowry. Article 35 paragraph 2 


\begin{tabular}{|c|c|c|c|}
\hline No. & Issues & Indonesia & Morocco \\
\hline 7. & $\begin{array}{l}\text { Regulation of dowry dis- } \\
\text { putes before entering the } \\
\text { household. }\end{array}$ & No regulation & Article 33 \\
\hline 8. & $\begin{array}{l}\text { Regulation of furniture dis- } \\
\text { putes other than the wife's } \\
\text { luggage }\end{array}$ & No regulation & Article 34 \\
\hline
\end{tabular}

If we pay a close attention, the dowry provisions in Indonesia in the KHI are influenced by the provisions of fiqh in the Shäfi'i school of thought, while the dowry provisions in Morocco are more or less influenced by the Mālikī school of thought. In addition, the anticipation of dowry disputes in Morocco is more detailed given the larger number of dowries and the important position of the dowry considering the potential for disputes regarding dowries in Morocco is larger compared to in Indonesia. Meanwhile, in Indonesia, the anticipation of such disputes is lesser as dowry disputes are relatively rare, as well as in many places given that the dowry matters are fairly simple.

\section{CONCLUSION}

Dowry is agreed by scholars as one of the obligations that must be fulfilled by the husband to his wife. But this is not a marriage pillar, according to majority of scholars. Only the Mālikī school considers dowry as a marriage pillar.

In Indonesia, the dowry regulation is in the compilation of Islamic law abbreviated as KHI, Chapter V Dowry, articles 30 to 38. This provision is not far too different from the provisions of fiqh in the Shāfi ‘í school which are generally quite easy and flexible in dowry matters as to make it easier for the bridegroom in carrying out marriages. In terms of the possibility of a dispute over a dowry, it is only briefly stipulated that it will be resolved in the religious court because in practice, it is rare for a dowry issue to be tried in a religious court in Indonesia.

In Morocco, the dowry regulations are regulated in Mudawawanah AlUsrah 2004 Chapter II as-sadaq from articles 26 to 34. The provisions are more influenced by the Mālikī School, the dominant school in Morocco. There is a striking similarity in dowry regulations in these two countries of which they both facilitate dowry payments by allowing dowry from anything of value according to shara' as well as emphasise in lowering down the payment in dowry, and provide a court in resolving disputes. 
As for the notable differences in Morocco and Indonesia, there are several articles that regulate and resolve if there is a dispute over the delivery of the dowry and the goods of each husband and wife in Morocco. While in Indonesia, it is only mentioned briefly that if there is a dispute over a dowry problem, it will be settled in a religious court.

\section{REFERENCES}

'Abd al-Raḥmān al-Jazirī, Kitāb al-Fiqh 'alā Madhāhib al-Arba 'ah (Bayrūt: Dār al-Kutub al-'Ilmiyyah, 2004).

Ahmad Rofiq, Hukum Perdata Islam di Indonesia (Depok: Rajawali Press, 2017).

Al-Shāfi ‘'̄, al-Umm, vol. 5 (Bayrūt: Dār al-Ma’rifah, 1393).

Amir Syarifuddin, Hukum Perkawinan Islam di Indonesia (Jakarta: Kencana, 2014).

Amiur Nuruddin \& Azhari Akmal Tarigan, Hukum Perdata Islam di Indonesia (Jakarta: Kencana, 2004).

Asriati, 'Pembaruan Hukum Islam dalam Terapan dan Perundang-Undangan di Indonesia', Jurnal Hukum Diktum, vol. 10/1 (2012): 23-39.

Fatimah Harrak, ' The History and Significance of The New Moroccan Family Code', http://www.cics.northwestern.edu/documents/workingpapers/ ISITA_09-002_Harrak.pdf, accessed on 22 January 2021.

Halimah B., ' Konsep Mahar (Maskawin) dalam Tafsir Kontemporer', Jurnal ad-Daulah, Vol. 6/2 (2017), 310-330.

Harijah Damis, ' Konsep Mahar dalam Perspektif Fikih dan PerundangUndangan Kajian Putusan Nomor 23 K/AG/2012', Jurnal Yudisial, vol. 9/1, (2016): 19-35.

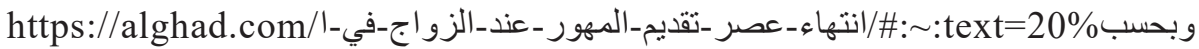

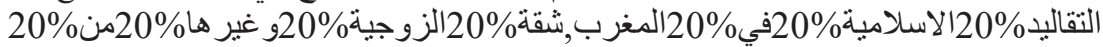
المنقو لات, accessed April 1, 2021.https://www.merdeka.com/gaya/ hantaran-seserahan-dan-mahar-apa-bedanya.html?page=3, accessed March 30, 2021.

https://en.wikipedia.org/wiki/Dowry\#Morocco, accessed April 3, 2021.

https://id.theasianparent.com/adat-pernikahan, accessed April 8, 2021

https://id.wikipedia.org/wiki/Kawin_lari\#, accessed April 6, 2021.

https://id.wikipedia.org/wiki/Suku_bangsa_di_Indonesia\#, accessed April 5, 2021. 
Ibn Qudāmah, al-Mughnī, Vol. 8 (Bayrūt: Dār al-Fikr,1405).

Ibn Rushd, Bidāyah al-Mujtahid wa Nihāyah al-Muqtașid (Mișr: Maṭba'ah Musțafā al-Bābī al-Ḥalābī wa Awlāduh, 1395).

Jalāl al-Dīn Muḥammad bin Aḥmad al-Maḥallī, Qalyubī wa 'Umayrah, vol. 3 (Bayrūt: Dār al-Fikr, 2001).

M.A. Tihami \& Sohari Sahrani, Fikih Munakahat: Kajian Fikih Nikah Lengkap (Depok: Rajawali Pers, 2018).

Mardani, Hukum Keluarga Islam di Indonesia (Jakarta: Kencana, 2016).

Mochammad Muslim, 'Pengaruh Konfigurasi Politik Hukum Orde Baru Terhadap Kompilasi Hukum Islam (KHI) di Indonesia', al-Daulah, vol. 4/1 (2014): 220-242.

Mohammad Azeemulkah, 'The evil practice of dowry in India and in the Arab world' dalam https://imesofindia.indiatimes.com/nri/citizen-journalists/ citizen-journalists-reports/mohammad-azeemullah/The-evil-practiceof-dowry-in-India-and-in-the-Arab-world/articleshow/19673234.cms, accessed on 30 January 2021.

Muhammad al-Faruj̄̄i, Mudawwanah al-Usrah (Dār al-Bayḍa': Maṭba'ah alNajāḥ al-Jadīdah, 2012).

Muhammad al-Shāfi'ī, al-Zawāj fì Mudawwanah al-Usrah (Marakesh: Mațba'ah Waraqah al-Wațaniyyah, n.d.).

Muhammad al-Shāfi'‘̄, Qānun al-Usrah fì Duwal al-Maghrīb al-'Arabī (Marakesh: Mațba'ah Waraqah al-Wațaniyyah, 2009).

Muḥammad Musṭafā Shiblī, Aḥām al-Usrah fì al-Islām (Bayrūt: Dār alJam'iyyah, 1403).

Muhammad Shobirin, 'Studi Komparasi Penerapan Mahar di Indonesia dan Malaysia', (Postgraduate Thesis, Program of al-Ahwal al-Shakhshiyyah UIN Maulana Malik Ibrahim Malang, 2013).

Muji Mulia, 'Pembaharuan Hukum Islam di Indonesia: Analisis Historis tentang Kompilasi Hukum Islam,' Islam Futura, vol. 7/1 (2008): 64-85.

Mutia Wardah, 'Hadhanah Akibat Perceraian dalam Hukum Keluarga di Indonesia dan Maroko', (Thesis, Program of Hukum Keluarga Islam Fakultas Syariah dan Hukum UIN Jakarta, 2018).

Nia Septyarani, 'Ketentuan Mahar dalam Perkawinan: Studi Komparatif Hukum Keluarga Islam Yordania dan Pakistan,' (Thesis, Department of Islamic Family Law, Faculty of Sharia, State Islamic Institute of Ponorogo 2019). 
Noryamin Aini, 'Tradisi Mahar di Ranah Lokalitas Umat Islam: Mahar dan Struktur Sosial di Masyarakat Muslim Indonesia,' Ahkam, vol. 14/1 (2014): 13-30.

Sālim bin 'Abd al-Mughn̄̄ al-Rāfi' '̄̄, Ahkām al-Ahwwāl al-Shakhșiyyah li alMusliminn fì al-Gharb (Bayrūt: Dār Ibn Hazm, 2003).

Sayyid Sābiq, Fiqh al-Sunnah, vol. 2 (Bayrūt: Dār al-Fikr, 1412).

Suparman Usman \& Yusuf Somawinata, Fiqh Mawaris (Jakarta: Gaya media Pratama, 2002).

'Umar Sid̄̄, 'al-Himāyah al-Qānūniyah li Haqq al-Zawjah fi al-Ṣadāq,' Majallah al-Ijtihād li al-Dirāsat al-Qānūniyyah wa al-Iqtiṣādiyah, vol. 8/2 (2019): 56-68.

Wahbah al-Zuhaylī, al-Fiqh al-Islāmi wa Adillatuh, vol. 9 (Dimashq: Dār alFikr, n.d.).

Wuzārah al-‘Adl, Dal̄̄l 'Amalī li Mudawwanah al-Usrah (Rabaṭ: Jam'iyyah al-Ma'lūmah al-Qānūniyyah wa al-Qaḍa'iyyah, 2004).

Wuzārah al-Awqāf wa al-Shu'ūn al-Islāmiyyah Kuwayt, al-Mawsū'ah alFiqhiyyah al-Kuwaytiyyah, vol. 38 (Mișr: Maṭabi’ Dār al-Ṣafwah, 1427).

\section{Statutes}

President of The Republic of Indonesia Instruction Number 1 of 1991 about Dissemination of Islamic Law Compilations (Inpres No. 1, 1991). 
Jurnal Syariah, Jil. 29, Bil. 2 (2021) 207-232 